\title{
Composition and Properties of Camel Milk In Comparison With Cow's and Buffaloes' Milks
}

\author{
A.M. Abd El-Aty; Sania M. Abdou; A.I. Aukasha* and G.M. Emara* \\ Food Sci., Dept., Faculty of Agric. Moshtohor, Benha University. \\ * Dairy Chem. Res. Dept., Animal Prod. Res. Inst., Agric., Res. Center.
}

\begin{abstract}
Camel, cow's and buffaloe's milk samples were randomly collected from the animal breeding in MarsaMatrouh, Res. Station. All samples were analysed for TS, fat, protein, lactose, Ca, P, acidity and pH value. Also, amino acids, fatty acids and protein fractionations were studied. Camel milk had a lower TS, protein, lactose, $\mathrm{Ca}, \mathrm{P}$, and acidity than cow's and buffaloes' milk. Also, camel milk contained lower CN/TN ratio, while it was higher in WP/TN and NPN/TN. Also, clear variations were detected in milk fat constants between the three different types of milk. The analysis of amino acids showed some variations between camel, cow, and buffaloe's milk. An obvious difference was observed in fatty acid contents between different species. Fractionation of proteins by electrophoresis showed a clear variation that the $\beta$-casein was high in camel milk and the $\kappa$-casein was very low, while $\beta$-lacto globulin was very low in camel milk. That it was similar with human milk in this property.
\end{abstract}

Key words: Camel, electrophoresis, fatty acids, amino acids

\section{Introduction}

Camels support the survival of millions of people in arid and semi-arid areas of the world. They possess remarkable abilities to exploit very limited resources because they are extremely well suited for life under harsh conditions of hot climates where water is frequently scarce. Also, they provide milk almost all year around in quantities much greater than other animals living under the same conditions (El-Agamy, 2006).

The camel is among the animals mentioned in the Holly Quran as a miracle of God. It is common practice to let camels to eat certain plants in order to use the milk for medicinal purpose (Yagil, 1986).

According to FAO statistics GLIPHA, 2006 (Global Livestock Production and Health Atlas) the world population of camels is about 20 million animals, mainly in arid Zones, of which 15 million camels live in Africa and 5 million in Asia.

The camel milk normally has a sweet and sharp taste, but sometimes can also have a salty taste due to the type of plants eaten in the desert by the camels (Khaskheli et al., 2005; Alwan and Igwebe, 2013). Camel milk assesses vital role in human nutrition in the hot regions and arid countries. It contains all the essential nutrients found in the bovine milk (El Agamy et al., 1998; Omer and Eltiney, 2009). It has hyperchlostrolimic effect (Elayan et al., 2008) and has been recommended to for by children who are allergic to bovine milk (Al Agamy et al., 2009). Camel milk containes a number of immunogoboulins that is compatible. Also, it has been used in different parts of the world in the treatment of a series of diseases such as dropsy, jaundice, tuberculosis, asthma, and leishmaniasis (Abdel gadir, et al., 1998; Shabo and Yagil 2005). Recently, camel milk was also reported to have other potential therapeutic properties such as anti-carcinogenic (Magieed, 2005), anti-diabetic (Agrawal, et al., 2007), antihypertensive (Quan et al., 2008) in the treatment of human viral related disease like: hepatitis $\mathrm{C}$ virus and immunity deficiencies (El-Agamy 2000; ElFakharany et al., 2008; Sboui et al., 2010; Salami et al., 2011 and JRAD Zeineb, et al., 2013).

The wide variation observed of camel's milk composition have been attributed to many factors such as analytical techniques used, geographical location, feeding, size of samples analyzed and breeds, in addition to milking frequency, stage of lactation and parity (FAO, 2001; Iqbal et al., 2001; Ayadi et al., 2009, Konuspayeva et al., 2009: AlHaj and Al-Kanhal, 2010; Hammadi et al., 2010; Aljumaah et al., 2011; Alwan et al., 2014).

Although the composition of camel milk has been studied in various parts of the world. The, available information on camel milk composition are limited in Egypt, especially amino acids and fatty acids composition. Therefore, the present investigation was to study some principal chemical composition, nitrogen distribution, amino acids, fatty acids analysis, and milk fat constant of camel milk compared with cow's and buffaloe's milk.

\section{Materials and Methods}

\section{Milk samples:}

Camel milk: Bulk normal milk samples (Camellus dromedaries) were obtained from the Animal Breeding in Marsa-Matrouh, Research Station, Animal Production Research Institute, Agriculture Research Center, Ministry of Agriculture. Buffaloe's milk: Fresh morning milk was obtained from Buffaloe's Herd Kept at Sakha 
(Kafre El Sheakh Governorate) of Animal Production Research Institute, Agriculture Research Centre, Ministry of Agriculture. Cow milk: Fresh morning milk was obtained from El-Gemmeza Animal Production Research Station herd (Gharbia Governorate), Animal Production Research Institute, Agriculture Research Center, Ministry of Agriculture, Egypt

\section{Methods of Analysis:}

The $\mathrm{pH}$ value of milk was determined using a glass electrode $\mathrm{pH}$ meter type (Digital HANNA instruments $\mathrm{pH}$ meter Hi 8014-Italy) according to BSI (1989). The titratable acidity, total solids and ash content of the milk were determined according to the methods described by AOAC (2010). The conventional Gerber's method was followed for determination of milk fat content as described in IDF (1996). Nitrogen distribution for milk was determined using the method of IDF (2001). Lactose content was determined according to the method of Lawrence (1968). Calcium content was determined by the method of Francesco and Raffaello (1980); while, total phosphorous content of milk was measured according to Olsen and Sommers (1982).

Amino acids were performed by analytical high performance liquid chromatograpghy (HPLC) method according to Millipore co-operative (1987).

Fatty acids determination was carried out by extracting milk lipids. The milk lipids first were extracted four times from milk using the method of Rose-Gottlieb as reported by Pearson (1976). Then Fatty acids were methylated by the procedure of Christie (2003) and directly injected into HP 6890
Series Gas Chromatograph System with an HP 5973 Mass Selective Detector.

Analysis of milk fat constants: Saponification, Rëichert - Mëssile, Polenske and Kirschner values of the milk fat were determined according to the methods of FAO/WHO (2001). Iodine value of the milk fat was determined using the method described by Murthy and Bhat (1976). The acid value of milk fat was performed according to Peason (1970). The refractive index of the milk fat was determined at $40^{\circ} \mathrm{C}$ using a carlzeiss refractometer according to AOAC (1980).

Gel electrophoresis analysis: Polyacrylamide gel electrophoresis was performed using the method of Laemmli, (1970).

Statistical analysis: analysis of data was carried out using SAS procedure guide (SAS, 2004).

\section{Results and Discussion}

\section{Chemical composition:}

Chemical composition of camel milk compared with cow's and buffaloe's milk is shown in Table (1). The $\mathrm{pH}$ value of camel milk recorded an average value of $6.7 \pm 0.06$ compared with $6.61 \pm 0.02$ and $6.60 \pm 0.01$ for cow's and buffaloe's milk, respectively. These result similar to that reported by Field $\boldsymbol{e t}$ al. (1997) and Khaskheli et al. (2005). However, it was slightly higher when compared to cow's milk and buffaloe's milk, while it was higher than those reported by Sawaya et al., (1984); Hassan et al. (1987); Ahmed, (1990); Farage and Kebary (1992).

EL-Loly et al. (2009) found that the $\mathrm{pH}$ values of camel milk ranged from 6.55 to 6.87 with an average value of 6.6 which confirmed the obtained results.

Table 1. Gross chemical composition of camel, cow's and buffaloe's milks (Mean + SE).

\begin{tabular}{|c|c|c|c|c|c|c|c|c|c|}
\hline Milk Type & $\mathrm{pH}$ & Acidity \% & T. S \% & $\begin{array}{c}\text { Fat } \\
\%\end{array}$ & T. P \% & Lactose $\%$ & $\begin{array}{c}\text { Ash } \\
\%\end{array}$ & $\begin{array}{c}\mathrm{Ca} \\
\mathrm{mg} / 100 \mathrm{~g}\end{array}$ & $\begin{array}{c}\mathrm{P} \\
\mathrm{mg} / 100 \mathrm{~g}\end{array}$ \\
\hline \multirow{2}{*}{ Camel } & 6.70 & 0.15 & 12.25 & 4.00 & 3.04 & 4.35 & 0.83 & 114.74 & 84.10 \\
\hline & $+0.06^{\mathrm{b}}$ & $+0.01^{\mathrm{a}}$ & $+1.87^{\mathrm{a}}$ & $\pm 1.16^{\mathrm{a}}$ & $\pm 0.44^{\mathrm{a}}$ & $+0.53^{\mathrm{a}}$ & $\pm 0.06^{\mathrm{b}}$ & $+0.73^{\mathrm{a}}$ & $\pm 2.04^{\mathrm{a}}$ \\
\hline \multirow{2}{*}{ Cow's } & 6.61 & 0.16 & 12.47 & 3.60 & 3.40 & 4.71 & 0.72 & 123.20 & 95.10 \\
\hline & $\pm 0.02^{\mathrm{a}}$ & $\pm 0.00^{\mathrm{ab}}$ & $\pm 0.31^{\mathrm{a}}$ & $\pm 0.13^{\mathrm{a}}$ & $\pm 0.11^{\mathrm{a}}$ & $\pm 0.06^{\mathrm{a}}$ & $\pm 0.02^{\mathrm{a}}$ & $\pm 2.29^{\mathrm{b}}$ & $\pm 2.27^{\mathrm{b}}$ \\
\hline \multirow{2}{*}{ Buffalo's } & $6.60 \mathrm{a}$ & 0.17 & 16.94 & 6.70 & 4.77 & 4.69 & 0.76 & 193.50 & 113.80 \\
\hline & $\pm 0.01^{\mathrm{a}}$ & $\pm 0.00^{\mathrm{b}}$ & $\pm 0.52^{\mathrm{b}}$ & $\pm 0.34^{\mathrm{b}}$ & $\pm 0.24^{\mathrm{b}}$ & $\pm 0.09^{\mathrm{a}}$ & $\pm 0.01^{\mathrm{a}}$ & $\pm 0.03^{\mathrm{c}}$ & $\pm 2.28^{\mathrm{c}}$ \\
\hline LSD at 0.05 & 0.05 & 0.01 & 1.39 & 0.86 & 0.36 & 0.39 & 0.05 & 2.99 & 2.71 \\
\hline
\end{tabular}

The values with the same superscript letter in the same column have no significant difference $(\mathrm{P}>0.05)$

The acidity of camel milk recorded an average of $0.15 \pm 0.01 \%$ compared with $0.16 \pm 0.00 \%$ and $0.17 \pm 0.00 \%$ for cow's and buffaloe's milk, respectively. These results in the vicinity of that reported by Al-Haj and Al-Kanhal (2010); and Rahli, et al. (2013) who reported that the acidity of camel milk is lower than that of cow's milk.

The total solids content of camel milk recorded an average of $12.25 \pm 1.87 \%$ compared with $12.47 \pm 0.31 \%$ and $16.94 \pm 0.52 \%$ for cow's and buffaloe's milk in order. These results are higher than those of Hassan et al. (1987), but lower than those of El-Agamy, (1983); Zhang et al. (2005) and Kamal et al. (2007).

The fat content of camel milk recorded an average of $4 \pm 1.6 \%$ compared with $3.6 \pm 0.13 \%$ and $6.7 \pm 0.34 \%$ for cow's and buffaloe's milk. Similar data were recorded by Farage and Kebary, (1992) and Kamal et al. (2007). These differences could reflect species differences and feeding conditions. Generally, fat percentages of camel milk vary with season, stage of lactation and pregnancy (Knoess et 
al., 1986, El-Amin 1979 and Rodriguez et al., 1985).

With regard to the total protein content of camel milk it recorded an average 3.04 \pm 0.44 compared with $3.40 \pm 0.11 \%$ and $4.77 \pm 0.24 \%$ for cow's and buffaloe's milk, respectively. It could be stressed that protein content of the feed as well as water intake have directly affected the protein quality of milk (FAO, 1982). Similar data were observed by Farag \& Kebray, (1992) and El-Loly et al. (2009) but lower than those of El-Agamy, (1983) and Kamal et al. (2007). Also, slightly lower comparing to cow's milk (3.40\%) and highly lower comparing to buffaloe's milk $(4.77 \%)$.

The average of lactose content of the analysed milk samples was $4.35 \pm 0.53 \% \quad 4.71 \pm 0.06 \%$ and $4.69 \pm 0.09 \%$ for camel, cow's and buffaloe's milks, in sequence. These results are in accordance with that reported by Farage and Kebray, (1992); while it was higher than that of Hassan et al. (1987); Haddadin et al. (2008), and lower than those of ElAgamy, (1983); Sawaya et al. (1984) and Kamal et al. (2007). This wide variation could be attributed to the variable chemical composition of the individual milk (Abu Lehia, 1990). The change of lactose concentration would be due to the type of plants eaten in the desert by the camel. (Farah, 1996; Khaskaheli et al., 2005 and Alwan and Iqwegbe, 2013).

Ash content of camel milk was $0.83 \pm 0.06 \%$. This result was higher than those reported by El-Agamy, (1983) and Kamal et al. (2007) but was lower than those reported by Knoess(1977) and EL-Loly (2009) while the obtained results are in line with Abu-Lehia (1987\&1989); Rahli et al. (2013) and Alwan et al. (2014), However, was higher when compared either with cow's $(0.72 \pm 0.02 \%)$ or buffaloe's $(0.76 \pm 0.01 \%)$ milks. The variations of ash content reflect the effects of genetic and environmental factors. ElAmin, (1979).

It is well known that milk salts play an important role in the physical status and stabilization of milk proteins. From such salts calcium and phosphorus. The ratio between calcium (cation) and phosphorus (anion) is known as the salt balance which is affected by stage of lactation, feeding and health status of the animal udder. The concentration of calcium and phosphorus of camel milk recorded $114.7 \pm 2.73$ and $84.1 \pm 2.04 \mathrm{mg} / 100 \mathrm{gm}$ compared with $123.2 \pm 2.29$ and 95.1 \pm 2.27 for cow's milk and 193.5 \pm 2.23 and 113.8 $\pm 2.28 \mathrm{mg} / 100 \mathrm{gm}$ for buffalo milk. These results are in accordance with that obtained by El-Agamy (2006).

The wide variation of the milk composition may be attributed to many factors i.e. (breed, age, the number of calving, nutrition management, the stage of lactation and the sampling technique used). AlHaj and Al-Kanhal, 2010; Hammadi et al., 2010); Al-Jumaah et al., 2011; Benyagoub, et al., 2013; and Alwan et al., (2014). In Addition, the fodder and water quality and quantity available to the animals also play an important role in this way. (FAO, 2001). Nitrogen distribution: Nitrogen distribution of camel milk protein $(\mathrm{mg} / 100 \mathrm{~g}$ milk) compared with cow's and buffaloe's milk protein are presented in Table (2).

From these results, it was obvious that the total nitrogen content of camel milk recorded 501.69 \pm 69.72 compared with $560.88 \quad \pm 18.9$ and $785.01 \pm 38.62 \mathrm{mg} / 100 \mathrm{gm}$ milk for cow's and buffalo's milk successively, while the protein nitrogen recorded $477.04 \pm 66.52,533.54 \pm 20.11$ and $747.91 \pm 36.62 \mathrm{mg} / 100 \mathrm{gm}$ milk for camel's, cow's and buffaloe's milk in the same order. The casein nitrogen was $355.20 \pm 46.86,450.00 \pm 13.67$ and $632.99 \pm 25.95 \mathrm{mg} / 100 \mathrm{gm}$ milk representing $70.80 \pm 1.14,80.23 \pm 0.58$ and $80.64 \pm 0.76 \%$ from the total nitrogen for camel, cow's and buffalo's milk, in the same order. The casein content of cow's and buffaloe's milks is higher than that of camel milk. These results are in agreement with that of Dyusembin and Rakhimberdiev (1975) and are lower than the findings of Shalash (1980).

Whey protein nitrogen was in average $121.84 \pm 20.6,83.54 \pm 5.11$ and $114.92 \pm 11.73 \mathrm{mg} / 100$ gm milk representing about $24.29 \pm 1.30,14.90 \pm 0.58$ and $14.64 \pm 0.80 \%$ from the total nitrogen for camel, cow's and buffaloe's milk, in sequence.

Table 2. Nitrogen distribution of camel, cow's and buffaloe's milks protein (mg/100g milk)

\begin{tabular}{|c|c|c|c|c|c|c|c|c|}
\hline Milk Type & $\mathrm{TN}$ & TPN & $\mathrm{CN}$ & $\begin{array}{c}\text { CN/T.N } \\
\%\end{array}$ & WPN & $\begin{array}{c}\text { WPN/ } \\
\text { TN } \\
\% \\
\end{array}$ & NPN & $\begin{array}{c}\text { NPN/ } \\
\text { TN } \\
\% \\
\end{array}$ \\
\hline Camel & $\begin{array}{r}501.69 \\
+69.72^{\mathrm{a}} \\
\end{array}$ & $\begin{array}{r}477.04 \\
+66.52^{\mathrm{a}} \\
\end{array}$ & $\begin{array}{r}355.20 \\
+46.86^{\mathrm{a}} \\
\end{array}$ & $\begin{array}{r}70.80 \\
+1.14^{\mathrm{a}} \\
\end{array}$ & $\begin{array}{r}121.84 \\
+20.6^{b} \\
\end{array}$ & $\begin{array}{r}24.29 \\
\pm 1.30^{\mathrm{b}} \\
\end{array}$ & $\begin{array}{r}24.65 \\
+3.75^{\mathrm{a}} \\
\end{array}$ & $\begin{array}{r}4.91 \\
+0.42^{\mathrm{a}} \\
\end{array}$ \\
\hline Cow's & $\begin{array}{r}560.88 \\
+18.9^{\mathrm{b}} \\
\end{array}$ & $\begin{array}{r}533.54 \\
+20.11^{\mathrm{a}} \\
\end{array}$ & $\begin{array}{r}450.00 \\
+13.67^{b} \\
\end{array}$ & $\begin{array}{r}80.23 \\
+0.58^{\mathrm{b}} \\
\end{array}$ & $\begin{array}{r}83.54 \\
+5.11^{\mathrm{a}} \\
\end{array}$ & $\begin{array}{r}14.90 \\
+0.58^{\mathrm{a}} \\
\end{array}$ & $\begin{array}{r}27.34 \\
+1.13^{\mathrm{a}} \\
\end{array}$ & $\begin{array}{r}4.88 \\
+0.07^{\mathrm{a}} \\
\end{array}$ \\
\hline Buffaloe's & $\begin{array}{r}785.01 \\
+38.62^{c} \\
\end{array}$ & $\begin{array}{r}747.91 \\
+36.62^{b} \\
\end{array}$ & $\begin{array}{r}632.99 \\
+25.95^{\mathrm{c}} \\
\end{array}$ & $\begin{array}{r}80.64 \\
+0.76^{\mathrm{b}} \\
\end{array}$ & $\begin{array}{r}114.92 \\
+11.73^{\mathrm{b}} \\
\end{array}$ & $\begin{array}{r}14.64 \\
+0.80^{\mathrm{a}} \\
\end{array}$ & $\begin{array}{r}37.10 \\
\pm 2.05^{\mathrm{b}} \\
\end{array}$ & $\begin{array}{r}4.73 \\
+0.06^{\mathrm{a}} \\
\end{array}$ \\
\hline LSD at 0.05 & 58.19 & 55.80 & 3.27 & 1.05 & 17.22 & 1.16 & 3.14 & 0.30 \\
\hline
\end{tabular}

The values with the same superscript letter in the same column have no significant difference $(\mathrm{P}>0.05)$ 
The results clear that the whey protein nitrogen for camel milk was higher than that ether of cow's or buffaloe's milk. These results are lower than the finding of El-Bahgy (1962) who found that whey protein nitrogen represents $27 \%$ of total nitrogen in case of camel milk. The average values of nonprotein nitrogen were $24.65 \pm 3.75,27.34 \pm 1.13$ and $37.10 \pm 2.05 \mathrm{mg} / 100 \mathrm{gm}$ milk representing $4.91 \pm 0.42$, $4.88 \pm 0.07$ and $4.73 \pm 0.06 \%$ from total nitrogen for camel, cow's and buffaloe's milk in sequence.

The ratio of non-protein nitrogen to total nitrogen of camel milk was more or similar to that of cow's and buffalo's milk. These results are similar to the findings of Abu-Lehia, et al., 1987; El-Agamy, 1983; Mehaia, et al., 1989, Mehaia, et al., 1995 and El-Agamy, 2006 who reported that the camel milks has higher content of whey proteins and slightly higher in their content of non-protein nitrogen than different animal milks.

Amino acids composition: Total amino acids composition of camel milk proteins (\%) compared with cow's and buffalo's milk proteins are presented in Table (3).

From the obtained results it was clear that overall amino acids composition of camel milk protein appears to be generally similar to that of cow's and buffaloe's milk proteins. The highest level of amino acids recorded for glutamic acid $(19.75 \pm 0.75 \%)$ in case of camel milk followed by cow's (18.58 \pm $0.42 \%)$ then buffaloe's milk $(16.44 \pm 0.44 \%)$. While, the proline represented $(10.42 \pm 0.23,9.59 \pm 0.10$ and $10.0 \pm 0.30 \%)$ and both of those two amino acids are from non-essential amino acids. On the other hand, the leucin recorded $(9.45 \pm 0.45,9.25 \pm 0.35$ and $9.88 \pm 0.22 \%$ ) for camel, cows and buffaloe's milks, respectively. The lysine recorded $7.04 \pm 0.26$, $8.11 \pm 0.08$ and $7.98 \pm 0.2 \%$ in order and both two types are from essential amino acids. Also, the glutamic \& praline represents the majority of nonessential amino acids. In the same way both of leucin and lysine represented the majority of essential amino acids.

Table 3. Total amino acids composition of camel. cow's and buffaloe's milk proteins (\%)

\begin{tabular}{|c|c|c|c|c|}
\hline Amino Acids & Camel & Cows & Buffaloe's & LSD at 0.05 \\
\hline \multicolumn{5}{|l|}{ Essential } \\
\hline Arginine & $4.01 \pm 0.09^{b}$ & $3.46 \pm 0.01^{\mathrm{a}}$ & $3.32 \pm 0.08^{\mathrm{a}}$ & $\begin{array}{l}0.18 \\
\end{array}$ \\
\hline Histidine & $2.64+0.06^{\mathrm{a}}$ & $3.080 .07^{\mathrm{b}}$ & $2.49 \pm 0.1^{\mathrm{a}}$ & 0.16 \\
\hline IsoLeucine & $5.08 \pm 0.12^{\mathrm{a}}$ & $4.920 .12^{\mathrm{a}}$ & $6.11 \pm 0.14^{b}$ & 0.25 \\
\hline Leucine & $9.45+0.45^{\mathrm{a}}$ & $9.25 \pm 0.35^{\mathrm{a}}$ & $9.88 \pm 0.22^{\mathrm{a}}$ & 0.70 \\
\hline Lysine & $7.04 \pm 0.26^{\mathrm{a}}$ & $8.11 \pm 0.24^{b}$ & $7.98 \pm 0.2^{\mathrm{b}}$ & 0.47 \\
\hline Methionine & $3.03+0.12^{b}$ & $2.34+0.08^{\mathrm{a}}$ & $2.32+0.08^{\mathrm{a}}$ & 0.19 \\
\hline phenylalanine & $4.87 \pm 0.26^{\mathrm{b}}$ & $4.26 \pm 0.34^{\mathrm{a}}$ & $4.05 \pm 0.2^{\mathrm{a}}$ & 0.54 \\
\hline Threonine & $5.70+0.40^{\mathrm{a}}$ & $6.00 \pm 0.45^{\mathrm{a}}$ & $8.23+0.22^{b}$ & 0.74 \\
\hline Tryptophan & $1.20 \pm 0.05^{\mathrm{a}}$ & $1.41 \pm 0.07^{\mathrm{b}}$ & $1.44 \pm 0.06^{\mathrm{b}}$ & 0.12 \\
\hline Valine & $6.61+0.38^{\mathrm{a}}$ & $6.82 \pm 0.48^{\mathrm{a}}$ & $7.26+0.14^{\mathrm{a}}$ & 0.72 \\
\hline Total E.A.A & $49.63+2.19^{\mathrm{a}}$ & $49.65 \pm 2.3^{\mathrm{a}}$ & $53.08+1.4^{\mathrm{a}}$ & 4.02 \\
\hline \multicolumn{5}{|l|}{ Non-essential } \\
\hline Alanine & $2.86 \pm 0.07^{\mathrm{a}}$ & $3.39 \pm 0.11^{b}$ & $4.05 \pm 0.1^{\mathrm{c}}$ & 0.19 \\
\hline Aspartic & $6.63+0.12^{b}$ & $6.96+0.14^{\mathrm{c}}$ & $5.96+0.14^{\mathrm{a}}$ & 0.27 \\
\hline Cystine & $1.02 \pm 0.02^{\mathrm{b}}$ & $0.81 \pm 0.04^{\mathrm{a}}$ & $2.13 \pm 0.07^{\mathrm{c}}$ & 0.10 \\
\hline Glycine & $1.39 \pm 0.06^{\mathrm{a}}$ & $2.11+0.09^{b}$ & $1.52 \pm 0.05^{\mathrm{a}}$ & 0.14 \\
\hline Glutamic & $19.75 \pm 0.75^{\mathrm{c}}$ & $18.58 \pm 0.42^{b}$ & $16.44 \pm 0.44^{\mathrm{a}}$ & 1.11 \\
\hline Proline & $10.42+0.23^{b}$ & $9.59+0.10^{\mathrm{a}}$ & $10.00+0.30^{\mathrm{ab}}$ & 0.45 \\
\hline Serine & $5.13 \pm 0.27^{\mathrm{a}}$ & $5.66 \pm 0.04^{b}$ & $4.76+0.24^{\mathrm{a}}$ & 0.42 \\
\hline Tyrosine & $4.14+0.21^{\mathrm{b}}$ & $4.50 \pm 0.2^{\mathrm{c}}$ & $3.11+0.08^{\mathrm{a}}$ & 0.35 \\
\hline Total N.E.A.A & $51.34 \pm 1.73^{b}$ & $51.6 \pm 1.14^{b}$ & $47.97 \pm 1.42^{\mathrm{a}}$ & 2.90 \\
\hline E.A.A / N.E.A.A & $0.97+0.01^{\mathrm{a}}$ & $0.962+0.02^{\mathrm{a}}$ & $1.11+0.00^{\mathrm{b}}$ & 0.03 \\
\hline
\end{tabular}

The values with the same superscript letter in the same column have no significant difference $(\mathrm{P}>0.05)$

The lowest values of essential amino acids were recorded for tryptophan $(1.20 \pm 0.05,1.41 \pm 0.07$ and $1.44 \pm 0.06 \%)$ and the lowest value of non- essential amino acids were recorded for cystine $(1.02 \pm 0.02$, $0.81 \pm 0.04$ and $2.13 \pm 0.07 \%$ ) for camel, cow's and buffaloe's milks, respectively. These results are in line with Taha and Kielwein (1990), Ahmed (1990), Guo et al. (2006), El-Loly et al. (2009) and Salmen, et al. (2012). The ratios of essential to non-essential amino acids were $0.97 \pm 0.01,0.96 \pm 0.02$ and $1.11 \pm 0.00$ for camel, cow's and buffaloe's milk, successively. Similar results were obtained by (ElAgamy and Nawar, 2000).

The quite variations of the amino acid content of different animal milks are attributed to be accompanied by differences in total protein contents. Camel milk proteins have the satisfactory quality balance of essential amino acids equalling or exceeding the requirements of $\mathbf{F A O / W H O / U N U}$ 
(1985) for each amino acid, therefore, it has the adequate nutritive values for human diets.

\section{Fatty acids composition:}

The lipids of milk play an important role in human nutrition, as an energy source, act as a solvent for fat-soluble vitamins and supply essential fatty acids. Fatty acids are the most important component of lipids, thus research dealing with milk fat has been focused mainly on fatty acids content of milk lipids.

Fatty acids composition of camel, cow's and buffaloe's milk fat are given in Table (4).

There are some variations in the fatty acids content of camel milk fat and the level of short-chain fatty acids $\left(\mathrm{C}_{4}-\mathrm{C}_{12}\right)$ in a small amount. The predominant saturated fatty acids were for $\mathrm{C}_{16}, \mathrm{C}_{18}$ and $\mathrm{C}_{14}$, in a sequence for all types of milk. Also, it has higher proportions of unsaturated fatty acids compared with cow's and buffaloe's milk fat. There was a considerable level of poly unsaturated fatty acids (mainly $\mathrm{C}_{18}$ ) is the most abundant in camel milk fat. Short chain fatty acids $\left(\mathrm{C}_{4}-\mathrm{C}_{12}\right)$ of camel milk have been reported to be in the range of $0.27 \pm 0.03$ (caprylic) to $0.69 \pm 0.09 \mathrm{gm} / 100 \mathrm{gm}$ fat (lauric) which were considerably lower than that of cow's $1.21 \pm 0.09$ (caprylic) to $3.05 \pm 0.15$ (butyric) and buffaloe's milk fat $0.84 \pm 0.09$ (caprylic) to $4.05 \pm 0.2$ (butyric). The fatty acids $\mathrm{C}_{16}, \mathrm{C}_{18}$ and $\mathrm{C}_{14}$ recorded the majority of saturated fatty acids for all milk types and recorded $28.88 \pm 1.12,12.99 \pm 0.77$ and $11.04 \pm 0.7 \%$ camel, cow's and buffaloe's milk, respectively. These results are similar to those of (Haddadin et al., 2008); Kamal and Salama, 2008; El-loly et al., 2009; Azza and Omar 2009 and Kanuspayeva et al., 2014.

Table 4. Fatty Acids composition (gm/100gm fat) of camel, cow's and buffaloe's milk fat.

\begin{tabular}{|c|c|c|c|c|}
\hline Fatty Acids & Camel & Cow's & Buffaloe's & $\begin{array}{c}\text { LSD at } \\
0.05\end{array}$ \\
\hline \multicolumn{5}{|l|}{ Saturated fatty acids } \\
\hline $\mathrm{C}_{4: 0}$ Butyric & $0.59 \pm 0.07^{\mathrm{a}}$ & $3.050 .15^{b}$ & $4.05 \pm 0.2^{\mathrm{c}}$ & 0.30 \\
\hline $\mathrm{C}_{6: 0}$ caproic & $0.39+0.06^{\mathrm{a}}$ & $1.70+0.10^{\mathrm{c}}$ & $1.41+0.09^{b}$ & 0.17 \\
\hline $\mathrm{C}_{800}$ Caprylic & $0.27+0.03^{\mathrm{a}}$ & $1.21+0.09^{\mathrm{c}}$ & $0.84+0.09^{b}$ & 0.15 \\
\hline $\mathrm{C}_{10: 0}$ Capric & $0.40 \pm 0.07^{\mathrm{a}}$ & $2.56+0.14^{\mathrm{c}}$ & $1.42+0.23^{b}$ & 0.32 \\
\hline $\mathrm{C}_{12: 0}$ Lauric & $0.69+0.09^{\mathrm{a}}$ & $2.60+0.15^{\mathrm{c}}$ & $1.90+0.25^{\mathrm{b}}$ & 0.35 \\
\hline $\mathrm{C}_{14: 0}$ Myristic & $11.04+0.70^{\mathrm{a}}$ & $10.71+1.28^{\mathrm{a}}$ & $10.05 \pm 1.00^{\mathrm{a}}$ & 2.04 \\
\hline $\mathrm{C}_{15: 0}$ Pentadecanic & $0.68+0.09^{\mathrm{a}}$ & $1.45+0.15^{\mathrm{b}}$ & $0.78+0.12^{\mathrm{a}}$ & 0.24 \\
\hline $\mathrm{C}_{16: 0}$ Palmitic & $28.88+1.12^{\mathrm{a}}$ & $30.68+1.42^{\mathrm{a}}$ & $30.41+1.5^{\mathrm{a}}$ & 2.71 \\
\hline $\mathrm{C}_{17: 0}$ Margaric & $0.70 \pm 0.09^{c}$ & $0.16+0.01^{\mathrm{a}}$ & $0.36+0.13^{b}$ & 0.18 \\
\hline $\mathrm{C}_{18: 0}$ Stearic & $12.99 \pm 0.77^{b}$ & $10.05 \pm 0.45^{\mathrm{a}}$ & $14.20 \pm 0.8^{b}$ & 1.38 \\
\hline $\mathrm{C}_{20: 0}$ Arachidic & $0.66 \pm 0.08^{b}$ & $0 \pm 0^{\mathrm{a}}$ & $1.05 \pm 0.1^{\mathrm{c}}$ & 0.15 \\
\hline Total Saturated Fatty acids(TSFA) & $57.29 \pm 3.17^{\text {a }}$ & $64.17^{\mathrm{ab}}$ & $66.47 \pm 4.51^{b}$ & 7.82 \\
\hline \multicolumn{5}{|l|}{ Unsaturated Fatty Acids } \\
\hline $\mathrm{C}_{10: 1}$ Caproleic & $0+0^{\mathrm{a}}$ & $0.10 \pm 0.01^{\mathrm{b}}$ & $0.20 \pm 0.03^{\mathrm{c}}$ & 0.04 \\
\hline $\mathrm{C}_{12: 0}$ Lauroleic & $0 \pm 0^{\mathrm{a}}$ & $0.58 \pm 0.12^{\mathrm{b}}$ & $0.09 \pm 0.02^{\mathrm{a}}$ & 0.14 \\
\hline $\mathrm{C}_{14: 1}$ Myristoleic & $1.38+0.12^{\mathrm{a}}$ & $2.03+0.17^{b}$ & $1.12+0.12^{\mathrm{a}}$ & 0.28 \\
\hline $\mathrm{C}_{16: 1}$ Palmitoleic & $10.29+1.00^{\mathrm{b}}$ & $2.59+0.21^{\mathrm{a}}$ & $2.13+0.17^{\mathrm{a}}$ & 1.19 \\
\hline $\mathrm{C}_{17: 1}$ Margaroleic & $0.64+0.09^{\mathrm{c}}$ & $0.22+0.01^{\mathrm{b}}$ & $0+0^{\mathrm{a}}$ & 0.10 \\
\hline $\mathrm{C}_{18: 1}$ Oleic (Omega7) & $25.39+1.61^{\mathrm{a}}$ & $27.00 \pm 1.25^{\mathrm{a}}$ & $26.75 \pm 1.00^{\mathrm{a}}$ & 2.62 \\
\hline $\mathrm{C}_{20: 1}$ Eicosenoic & $0.35+0.05^{\mathrm{b}}$ & $0+0^{\mathrm{a}}$ & $0+0^{\mathrm{a}}$ & 0.06 \\
\hline $\mathrm{C}_{22: 1}$ Erucic (omega9) & $0.07 \pm 0.09^{\mathrm{a}}$ & $0 \pm 0^{\mathrm{a}}$ & $0 \pm 0^{\mathrm{a}}$ & 0.10 \\
\hline $\mathrm{C}_{16: 2}$ Hexadecdienoic & $0+0^{\mathrm{a}}$ & $0+0^{\mathrm{a}}$ & $0.50+0.1^{\mathrm{b}}$ & 0.12 \\
\hline $\mathrm{C}_{18: 2}$ Linoleic & $3.63 \pm 0.3^{\mathrm{c}}$ & $2.54 \pm 0.16^{b}$ & $1.90 \pm 0.3^{\mathrm{a}}$ & 0.52 \\
\hline $\mathrm{C}_{18: 3}$ Linolenic & $2.00+0.10^{\mathrm{a}}$ & $0.70+0.15^{\mathrm{a}}$ & $0.79 \pm 0.20^{\mathrm{a}}$ & 0.31 \\
\hline $\mathrm{C}_{20: 4}$ Arachidonic & $0 \pm 0^{\mathrm{a}}$ & $0 \pm 0^{\mathrm{a}}$ & $0.09 \pm 0.01^{\mathrm{b}}$ & 0.01 \\
\hline Total unsaturated Fatty Acids(TUSFA) & $42.696+3.35^{b}$ & $35.76+2.08^{a}$ & $33.57+1.95^{\mathrm{a}}$ & 5.07 \\
\hline TUSFA/TSFA & $0.745+0.02^{\mathrm{c}}$ & $0.553+0^{\mathrm{b}}$ & $0.505+0.01^{\mathrm{a}}$ & 0.02 \\
\hline
\end{tabular}

The values with the same superscript letter in the same column have no significant difference $(\mathrm{P}>0.05)$

Camel milk fat also has higher proportions of mono unsaturated fatty acids $\mathrm{C}_{16: 1}$ present in greater portions in camel milk $(10.29 \mathrm{~g} / 100 \mathrm{~g})$ than cow's $(2.59 \mathrm{~g} / 100 \mathrm{~g})$ and buffaloe's milk $(2.13 \mathrm{~g} / 100 \mathrm{~g})$. On the other hand, poly unsaturated fatty acids $\left(\mathrm{C}_{18: 2}\right.$ and
$\mathrm{C}_{18-3}$ ) are relatively high in camel milk (3.63 and $2.00 \mathrm{~g} / 100 \mathrm{~g})$ compared with cow (2.54 and 0.70 $\mathrm{g} / 100 \mathrm{~g}$ ) and buffaloe's milk (1.90 and $0.79 \mathrm{~g} / 100 \mathrm{~g})$, respectively. The most abundant unsaturated fatty acids are present at higher amount in camel milk fat (El-Agamy 2006 and El-Loly et al.,, 2009) but lower amount than that recorded by Abu-Lehia 1989 for 
cow. According to Gnan and Sheriha (1986) who mentioned camel milk fat contained relatively high levels of poly unsaturated fatty acids, which essential for human nutrition especially linolenic $\left(\mathrm{C}_{18: 3}\right)$ and linoleic $\left(\mathrm{C}_{18: 2}\right)$ acids.

Moreover, SAFAs represented $57.29 \%$ of the total fatty acids. Similar results are give by Farag and Kebary (1992) and was higher than those of Gobran and Izzeldin (1999) (52\%), but lower than that reported by Czech et al., (2005). Thus, these differences can partially explained by different factors that affect on the fatty acid composition of camel milk include breed, feeding, composition of dietary fat, dietary protein, seasonality and region and stage of lactation (Palmquist et al., 1993; Gobran and Izzeldin 2001).

\section{Milk fat constants:}

Milk fat constants of camel, cow's and buffaloe's milk are presented in Table (5). Physical and chemical constants have been derived for the characterization of the types of fatty acid components present in milk fats. They also enable the detection of fat adulteration qualitatively and quantitatively. Highly significant variations among the three types of milk are found especially between camel milk and that of cow's and buffaloe's. Camel milk fat is higher in refractive index, iodine value and acid value which recorded about $1.4756 \pm 0.001,47.85 \pm 1.15$ and $0.49 \pm .02$, respectively compared with $1.4535 \pm 0.001$, $32.00 \pm 0.79$ and $0.25 \pm 0.01$ for cow's and $1.4594 \pm 0.001, \quad 31.68 \pm 0.74$ and $0.29 \pm 0.01$ for buffaloe's milk in the same order. low saponification, Reichert Meissl, Polenske and Kirschner values were recorded, since it has $190.05 \pm 3.20,16.43 \pm 1.44,0.86$ \pm 0.15 and $10.41 \pm 0.64$, respectively for camel milk compared with $228.65 \pm 3.32,26.57 \pm 2.34,1.81 \pm 0.29$ and $25.5 \pm 1.46$ for cow's and 230.47 \pm 3.51 , $32.17 \pm 2.19,1.59 \pm 0.21$ and $31.60 \pm 1.4$ for buffaloe's milk fat, in the same order. This reflects its higher content of long-chain fatty acids $\left(\mathrm{C}_{14}-\mathrm{C}_{18}\right)$ and lower content of short-chain fatty acids $\left(\mathrm{C}_{4}-\mathrm{C}_{12}\right)$. These results are in agreement with that reported by ElAgamy (2006).

\section{Electrophoresis of protein fractions:}

Milk proteins can be separated and identified by molecular mass (Mol. Weight in Kilo Daltons). One method of separating proteins is by poly acrylamide gel electrophoresis. This method essentially separates the proteins by molecular mass, with the largest proteins migrating more slowly in the gel and remaining near the top and the smaller proteins migrating more rapidly toward the bottom of the gel.

Table 5. Milk fat constants of camel milk, compared to Cow's and Buffaloe's milk (Mean + SE).

\begin{tabular}{|c|c|c|c|c|}
\hline \multirow{2}{*}{ Parameter } & \multicolumn{3}{|c|}{ Milk type } & \multirow{2}{*}{$\begin{array}{c}\text { LSD at } \\
0.05\end{array}$} \\
\hline & Camel & Cow & Buffalo & \\
\hline Refractive index $\left(40^{\circ} \mathrm{C}\right)$ & $\begin{array}{l}1.4756+ \\
0.0001^{b}\end{array}$ & $\begin{array}{l}1.4535 \pm \\
0.0001^{a}\end{array}$ & $\begin{array}{l}1.4594 \pm \\
0.0001^{\mathrm{c}}\end{array}$ & 0.0002 \\
\hline Iodine Value gm Iodine/100 gm fat & $\begin{array}{c}47.85 \pm \\
1.15^{\mathrm{b}}\end{array}$ & $\begin{array}{c}32.00 \pm \\
0.79^{\mathrm{a}}\end{array}$ & $\begin{array}{c}31.68 \pm \\
0.74^{\mathrm{a}}\end{array}$ & 1.82 \\
\hline Saponification Value mg KoH/gm fat & $\begin{array}{c}190.05 \pm \\
3.20^{\mathrm{a}}\end{array}$ & $\begin{array}{r}228.65 \pm \\
3.32^{b}\end{array}$ & $\begin{array}{c}230.47 \pm \\
3.51^{b}\end{array}$ & 6.68 \\
\hline Reichert - Messile Value & $\begin{array}{c}16.43 \pm \\
1.44^{\mathrm{a}}\end{array}$ & $\begin{array}{c}26.57 \pm \\
2.34^{\mathrm{b}}\end{array}$ & $\begin{array}{r}32.17 \pm \\
2.19^{\underline{c}}\end{array}$ & 4.05 \\
\hline Polenske Value & $\begin{array}{l}0.86 \pm \\
0.15^{\mathrm{a}}\end{array}$ & $\begin{array}{l}1.81 \pm \\
0.29^{b}\end{array}$ & $\begin{array}{l}1.59+ \\
0.21^{\mathrm{b}}\end{array}$ & 0.45 \\
\hline Kirschner Value & $\begin{array}{c}10.41 \pm \\
0.64^{\mathrm{a}}\end{array}$ & $\begin{array}{c}25.50 \pm \\
1.46^{b}\end{array}$ & $\begin{array}{l}31.6 \pm \\
1.40^{c}\end{array}$ & 2.45 \\
\hline Acid Value & $\begin{array}{l}0.49 \pm \\
0.02^{\bar{c}}\end{array}$ & $\begin{array}{l}0.25 \pm \\
0.01^{\mathrm{a}}\end{array}$ & $\begin{array}{l}0.29+ \\
0.01^{b}\end{array}$ & 0.03 \\
\hline
\end{tabular}

The values with the same superscript letter in the same raw have no significant difference $(\mathrm{P}>0.05)$

The relative size of the caseins $(\sim 25-35 \mathrm{KDa})$ vs the major whey proteins $\beta$-lactoglobulines ( $18 \mathrm{kDa})$ and Lactalbumin $(\sim 14 \mathrm{KDa})$. Others include primary lactoferrin $(\sim 80 \mathrm{KDa})$ and serum $\operatorname{albumin}(\sim 66$ $\mathrm{KDa})$. To assess the relative molecular weight of a protein on a gel, protein molecular weight marker is run in the outer lanes of the gel for comparison. The different proteins appear as distinct blue- stained bounds on the finished stained gel. From the positions and intensities of these bands, we can determine the size and relative abundance of the the proteins based on available reference. In this study, it is important to identify the proteins in camel milk compared with cow's and buffalo's milk. Fig (1) shows the electrophoretic patterns of whole milk protein of camel, cow's and buffaloe's.

Results showed that the relative migration of casein bands were not identical. In camel caseins, the relative migration of $\alpha_{-}, \beta$ - and $K$-Casein was slower than those of cow and buffalo casein. The same trend was observed by Metwalli and Al-Saleh (2010) and El-Agamy et al. (2009) and Salah et al. (2012). This indicates the differences in molecular weight of camel, cow's and buffaloe's caseins. 
Differences in electrophoretic patterns of whey proteins (WPs) of the three types of milk are clear. It is obvious that the major WP bands in cow's and buffaloe's milk belong to serum albumin (SA), $\beta$ lactoglobulin $(\beta$-lg) and $\alpha$-lactalbumin $(\alpha$-la), where as in camel milk WPs pattern, $\beta$-lg was minor band.The very low or absence of $\beta$-lg in camel milk makes it compatible with human milk and it is suitable to children who are allergic to bovine milk. However, the bands of SA and $\alpha$-la (as well as another unknown fraction) were found in high intensities. Similar results were obtained by Farah (1986) and El-Agamy (2000).

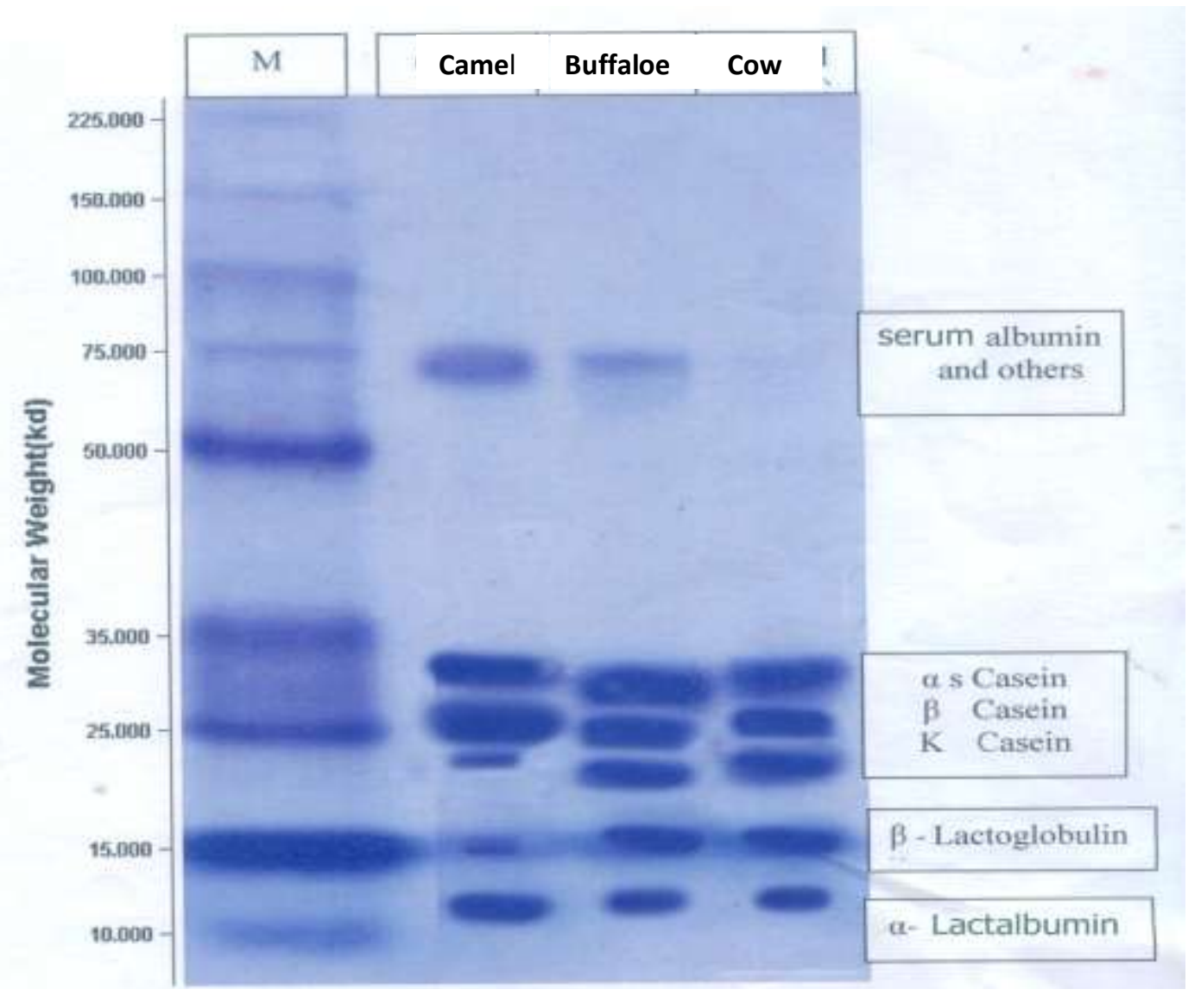

Fig. 1. Polyaccrylamide gel electrophoresis of proteins for Camel milk (lane 1), buffaloe's milk (lane 2), and cow's milk (lane 3) compared with marker (M).

\section{References}

Abdelgadir, W.S., Ahmed, T.K. and Dirar, H.A (1998). The traditional fermented milk products of the Sudan. Intnl. J. Food Microbiol., 44: 1-13.

Abu-Lehia, I.H. (1987). Composition of camel milk. Milchwissenschaft, 42:368-371

Abu-Lehia, I.H. (1989). Physical and chemical characteristics of camel milk fat and its fractions. Food chem.. 34: 261-271.

Abu-Lehia, I.H. (1990). The viable content of lactose and chloride in camel milk. Egypt. J. Dairy Sci. $18,2: 303-314$.

Agrawal, R.P., Budania. S., Sharma, P., Gupta, R And Kochar, D.K. (2007). Zero revalence of diabetes in camel milk consuming. Raica community of Northwest Rajasthan, India. Diabetes Res. Clin. Pract., 76: 290 - 296
Ahmed, M.M. (1990). The Analysis and Quality of camel milk. Index of the thesis accepted for higher degrees by Universities of Great Britain and Ireland and the councils for National Academic Awards. 38: 1356.

Al haj, O.A and Al Kanhal, H.A. (2010). Compositional, technological and nutritional aspects of dromedary camel milk: a review, Intnl. Dairy J., 10: 10-16.

Aljumaah, R.S., Almutairi, F.F., Ayadi, M.A., Alshaikh, A.M. and Hussein, M.F. (2011). Factors influencing the prevalence of subclinical mastitis in lactating dromedary camels in Riyadh region, Saudi Arabia. Trop. Anim. Health Prod., 43(8):1605-1610

Alwan, A.O and Igwgebe, A.O. (2013). Physicochemical Properties of Stirred-Curd Cheddar Cheese Manufactured from Farm-reared Camel and Cow's Milk: A Comparative Study. Accepted 
for Publication in Scottish J. Art Sci. Studies, 2014.

Alwan, A.O.; Igwgebe, A.O and Ahmed, A.A. (2014). Effects of rearing conditions on the proximate composition of Libyan Maghrebi camel (Camelus Dromedarius) milk. International Journal of Engineering and Applied Sciences. Vol 4, No.8

AOAC (2010). The official method of analysis, $18^{\text {th }}$ ed., association of official Analytical Chemists, Inc., Allington, Virginia, USA.

Ayadi, M., Hammadi, T. Khorchani, A. Barmat, M.A. and Caja, G.(2009). Effect of milking interval and cisternal udder evaluation in Tunnisian Maghrebi dairy dromedaries (Camelus dromedaries. L) J.Dairy Sci., 92: 1452-1459

Benyagoub, Elh., Ayat, M., Dahan, T., and Samahi, K. (2013). Level of control of the hygienic quality of camel milk (Camelus Dromedarius) in south west Algeria and its impact on security, J. of Food Sci and techn. Vol 1(4), 53-60. Peak

BSI (1989). British standards Institution. Methods for chemical analysis of milk and milk products. Determination of PH value BS: 770, part 4.

Christie, W. W., (2003). 13-phenyltridec-9-enoic and 15-phenylpentadec-9-enoic acids in Arum maculatum seed oil. Eur. J. Lipid Sci. Technol 105: 779-780.

Dyusembin, KH. D. and Rakhimberdiev, S. A. (1975). Some problems of physiology of milk formation in female camels. Trudy Instituta Fiziologiii, Alma-Ata, Kazokh SSR 21, 122-127, 158 C.F. DSA 38 (7) 4293 (1976).

Dyusembin, KH.D. and Rakhimberdiev, S.A. (1975). Some problems of physiology of milk formation in female camels. Trudy Instituta Fiziologii, Alma-ata, Kazokh SSR 21, 122-127, 158 C.F. DSA 38 (7) 4293 (1976).

El-Agamy, E. i. and Nawar, M.A. (2004). The $9^{\text {th }}$ Egyptian Conf. for dairy sci. \& Tech. "Milk and dairy products for a healthy future", Dokki, 9-11 October (2004), Cairo, Egypt.

El-Agamy, E.I. (1983). Studies on camel's milk. M. Sc. Thesis. Alexandria University, Alexandria, Egypt.

El-Agamy, E.I., Zienab, I. A.-S., and Abdel-Kader, Y.I. (1998). Gel electrophoresis of proteins, physicochemical characterization and vitamin $\mathrm{C}$ content of milk of different species. Alex. J.Agric. Res. 43(2):57-70.

El-Agamy, E.I; Nawar, M.A.; Shamsia, S.M, Awad, S. and Heanlein, G.F.W. (2009). Are camel milk proteins convenient to the nutrition of caw milk allergic children. Sma. Rum. Res., 82, PP 1-6

El-Agamy, E.l. (2000). Effect of heat treatment on camel milk proteins with respect to antimicrobial factors: A comparison with cows' and buffalo milk proteins. Food Chem. 68: 227-232

El-Agamy, E.1. (2006). Camel Milk. ln: Handbook of Milk of Non Bovine Mammals. Young W. Park and George F.W. Haenlein, ed. Blackwell Publishing Professional 2121 State Avenue, Ames, Iowa 50014, USA, pp 297-344.

El-Amin, F.M. (1979). The dromedary camel milk of Sudan. In Proc Workshop on Camels. Int. Found. Sci., Stockholm

ElAyan, A.A., Sulieman, A.E. and Saleh, F.A. (2008). The hypocholesterolemic effect of Gariss and Gariss containing Bifidobacteria in rats fed on a cholesterol- enriched diet. Asian Journal of Biochemistry. Vol 3, P. 43-47.

El-Bahay, G.M. (1962). Normal contents of Egyptian camel milk. Egyptian Vet. Med. J. 8: 7-17.

El-Fakharany E. M, Tabll A, Abd El-Wahab A, Haroun B.M, Redwan E.M (2008). Potential Activity of camel Milk-Amylase and Lactoferrin against Hepatitis C Virus Infectivity in HepG2 and Lymphocytes. Hepat.Monthly. 8: 101-109

El-Loly, M.M.; Zaghloul, A.H. and El-Sheikh, M.M. (2009). Physico-chemical and Biological characteristics of camel milk. J.Agric. Sci Mansoura Univ., 35 (4) ; 2981-2996

FAO (2001). Food and Agriculture Organization of the United Nations. Rome. 113 The Technology of making cheese from camel milk (Camelus dromadarius) Chapter 1.

FAO, (1982). FAO Animal Production and Health Papers. Camels and Camel Milk. Food Agriculture Organization of the United Nations, Rome, italy.

FAO/WHO (2001). Food and Agriculture Organization and World Health Organization, The Codex Alinentarius. Rome: FAO/WHO Vol 8 : Fats and Oils "Section 4.9.1 Estimation of Milk Fat Content".

FAO/WHO/UNU (1985). Energy and protein requirements. WHO Technical Report Series Nr. 724, WHO, Geneva.

Farag, S.l. and Kebary, K.M.K. (1992). Chemical composition and physical properties of camel's milk and milk fat. 'In Proc. $5^{\text {th }}$ Egyptian Conf. of Dairy Science and Technology,Egypt, pp. 57-67.

Farah, Z, (1986). Effect of heat treatment on whey proteins of camel milk. Milchwissenschaft 41, 763,765

Farah, Z. (1996). Camel Milk; Properties and Products. SKAT, Swiss Centre for Development Cooperation in Technology and Management, St. Gallen, Switzerland.

Farah, Z. (2004) An introduction to the camel. ln: Farah, Z. \& Fischer, A. (eds): Milk and meat from the camel-Handbook on products and processing. vdf Hochschulverlag, ZÜrich, Switzerland, pp. 15-28.

Farah, Z.; Streiff, T. and Bachmann, M.R. (1989). Manufacture and characterization of camel milk butter. Milchwissenschaft 44: 412-414.

Field, C.R.; Kinoti, M. and Bush, M. (1997). Camel milk for schools and its preservation during vacations. J. Camel Res. 4: 247-255. 
Francesco, G. and Raffaello, S. (1980). Use of a PH state to indicate the end point in titration of calcium plus magnesium in milk and whey. $\mathrm{J}$. Dairy Res, 47: 417-419.

GLIPHA (Global Livestock Production and Health Atlas) (2006). Global livestock production and health atlas of the FAO. (http://www.fao.org/ag/aga/ glipha/index.isp).

Gnan, S.O. and Sheriha A.M (1986) Composition of Libyan camel's milk Aust. J. Dairy Technol. 41: 33-35.

Gorban, A.M.S and Izzeldin, O.M. (1999). Study on cholesterol ester fatty acids in camel and cow milk lipid and colostrum. Int. J. of Food SCi. Technol. 34, 3: 229-234

Gorban, A.M.S and Izzeldin, O.M. (2001). Fatty acids and lipids of camel milk. Int. J.Food SCI. Nut 52 (3): 283-287

Guo, H. Y, Pang, X.Y, Zhang, L., Zhao, S.W., Chen, M.L., and Dong. F.Z. Ren (2007) Composition, Physio-chemical properties, Nitrogen fraction Distribution, and amino acids profile of donkey milk. J. of Dairy Sci 90 (4): 1635-1643

Haddadin, M.S.Y.; Gammoh, S.l. and Robinson, R.K. (2008). Seasonal variations in the chemical composition of camel milk in Jordan. J. Dairy Res. 75: 8-12.

Hammadi, M., Atigui, M., Ayadi, A., Barmat, A., Belgacem, G. K and Khorchani, T.(2010). Training period and short time yield and milk composition in Tunisian Maghrebi dromedaries . L). J.Camel Pract. Res., 17:1-7

Hassan, A.A.; Hagrass, A.E.; Soryal, K.A. and ElShabrawy, S.A. (1987). Physicochemical properties of camel milk during lactation period in Egypt. Egypt J. Food Sci. 15: 1-14.

IDF (1996). International dairy Federation. Milk, Determination of Fat Content. 001D.

IDF (2001). International Dairy Federation. Milk and milk products. Determination of nitrogen contentpart 1: Kjedldahl method 020-1.

Iqbal, A., Gill, R.M and Younas, M.(2001). Milk composition of Pakistani camel (Camelus dromedaries) Kept under station / farmer's condition. Emir. J. Agric. Sci., 13:7-10.

Jrad, Z; El Hatmi, H; Fguiri, I., Arroum, S.; Assadi M. and Khorchani, T. (2013) Antibacterial activity of Lactic acid bacteria isolated from Tunisian camel milk. African J. of Microbiology Research, Vol 7(12), pp 1002-1008.

Kamal, A.M. and Salama, A.O. and El-Saied, K.M. (2007). Changes in amino acids profile of camel milk protein during the early lactation. Int. J.Dairy Sci. 2 (3): 226-234.

Kamal, A.M. and Salama, O.A (2009). Lipid fractions and fatty acid composition of colostrum, transitional and mature she-camel milk during the first month of lactation. Asian J.Clinical Nut., 1: 23-30.
Khaskheli, M; Arain, M.A.; Chaudhry, S.; Soomro, A.H. and Qureshi, T.A. (2005). Physico-chemical quality of camel milk.J. Agri. Soc. Sci., 1, 2:164166.

Knoess, K.H. (1977). The camel as a meat and milk animal. World Anim. Rev., 22: 39-44.

Knoess, K.H.; Makhudum, A.J.; Rafiq, M. and Hafeez, M. (1986). Milk production potential of the dromedary, with special reference to the province of Punjab, Pakistan. World Anim. Rev., 57: 1I-21.

Konuspayeva, G., Faye, B., and Loiseau, G.(2009). The composition of camel milk: a meta- analysis of the literature data. J.Food Comp. Analysis, $22: 95-101$.

Lawrence (1968). The determination of lactose in milk products. Aust. J. Dairy Tech., 23: 103-106.

Magjeed, N.A. (2005). Corrective effect of milk camel on some cancer biomarkers in blood of rats intoxicated with aflatoxin B1. J.Saudi Chem. Society, 9:253 - 263

Mehaia, M.A. and Al-Kahnal, M.A. (1989). Studies on camel and goat milk proteins: Nitrogen distribution and amino acid composition. Nutr. Reports Int. 39 (2): 351-357.

Mehaia, M.A., Hablas, M.A., Abdel-Rahman, K.M., and El-Mougy. S.A. (1995). Milk composition of Majaheim. Wadah, Hamra camels in Saudi Arabia. Food Chem. 52(2):115-122

Metwalli, A.M and Al-Saleh, A.A (2010) Susceptibility of camel, Buffalo and cow milk caseins to proteolysis by different proteolytic enzymes. J.King Saud Univ Agric. SCI., 22. PP 59-69

Millpare co-operative (1987). Liquid chromatographic analysis of amino acids in foods using a modification of the PICO-TAG method.

Murthy, M.K. and Bhat, G.S. (1976) Iodine number determination of milk fat and vegetable fats by refractometry. Joural of the American Oil Chemists Society, Vol 53, Issue 9, PP 577-580.

Nirmalan, G. and Nair, M. K. (1962). Kerala Vet. 1 49. C. F. DSA 30 (2) 67-87 (1968).

Olsen, S.R. and Sammers, L.E. (1982). "phosphours" PP.403. in A.L. page et al (Eds). Method of soil analysis, part $22^{\text {nd }}$ Ed., Amer. Soc. Madison, Wisconsin, USA.

Omer, R.H. and ElTinay, A.H. (2009). Changes in chemical composition of camel's raw milk during storage. Pakistan journal of Nutrition, Vol 8, P: 607-610.

Palmquirst, D.L.; Beaulieu, A.D. and Barbano, D.M. (1993). Feed and animal factors influencing milk fat composition. J. Dairy Sci. 76: 1753-1771

Pearson, D., (1976). The chemical Analysis of Food. $7^{\text {th }}$ ed., Churchill Livingstone, London, ISBN: 0443014116, p: 7-11.

Pearson. D. (1970). The chemical analysis of foods. J.A. Churchill, London 
Quan, S., Tsuda, H. and Miyamoto, T. (2008). Angiotensin I-converting enzyme inhibitory peptides in skim milk fermented with Lactobacillus helveticus 130B4 from camel milk in Inner Mongolia, China. J. Sci Food Agric. 88:2688 - 2692

Rahli, Fouzia; Noureddin, S.; and Mebrouk, K. (2013). Evaluation of the factors affecting the variation of the physicochemical composition of Algerian camel's raw milk during different seasons. Advances in Environmental Biology, 7 (14). 4879-4884

Rao, M.B., Gupta, R.C and Dastur, N.N. (1970). Camel milk and milk products. Indian J. of Dairy Sci. 23 (2), 71-78

Rodriguez, L.A.; Mekonnen, G.; Wilcox, C.J.; Martin, F.G. and Krienke, W.A. (1985). Effects of relative humidity, maximum and minimum temperature, pregnancy, and stage of lactation on milk composition and yield. J. Dairy Sci. 68, 4: 973-978.

Salami M. Moosavi-movahedi A.A, Movahedi F.M, Ehsani M.R, Yousefi R, Farhadi M, Naslaji A.N, Saboury A.A, chobert JM, and Haertle T (2011). Biological activity of camel milk casein following enzymatic digestion. J. Dairy. Res. 78: 471-478.

Salmen, S.H., Abu-Tarboush, H.M.; Al-Saleh, A.A.; and Metwalli, A.A.(2012). Amino acids content and electrophotric profile of camel milk casein from different breeds in Saudi Arabia. Saudi. J. of Biological Sci 19, 177-183

SAS (2004). SAS Procedure guide version $6.12^{\text {th }}$ Ed., SAS institute Ine., Cary, NC, USA.
Sawaya, W.N.; Khalil, J.K.; Al-Shalhat, A.F. and AlMohammad, H. (1984). Chemical composition and nutritional quality of camel milk. J. Food Sci., 49, 3: 744-747.

Sboui A, Djegham M, Khorchani T, Hammadi M, Barhoumi K, Belhej O. (2010). Effect of camel milk on blood glucose, cholesterol and total proteins variations in alloxan-induced diabetics dogs. Int. J. Diabetes. Met. 18: 5-11

Shabo, Y., and Yagil. R. (2005). Behavioral improvement of autistic children following drinking camel milk. In: treating Persons with Brain Damage. $4^{\text {th }}$ National conference. Tel Aviv, Israel.

Shalash, M.R (1980). Utilization of camel meat and milk in human nourishment. International foundation for science No. 6, 286-306 (En, 29 ref.). C.F. DSA 43 (19) 6475 (1981).

Taha N.M. and Kielwein, G. (1990). Pattern of peptide-bound and free amino acids in camel, buffalo and ass milk. Milchwissenschaft 45:2225.

Yagil, R. (1986). The camel: self-sufficiency in animal protein in drought stricken areas. World Animal Rev. 57: 2-10.

Yagil, R.; Zagorski, O.; van Creveld, C. and Saran, A. (1994). Science and camel's milk production. Chameux et dromedaries, animeaux laitiers. Ed. Saint Marin, G. Expansion Scientifique Francais , Paris, 75-89.

Zhang H.; Yao, J.; Zhao, D.; Liu, H.; Li, J. and Guo, M. (2005). Changes in chemical composition of Alxa bactrian camel milk during lactation. J. Dairy Sci. 88: 3402-3410.

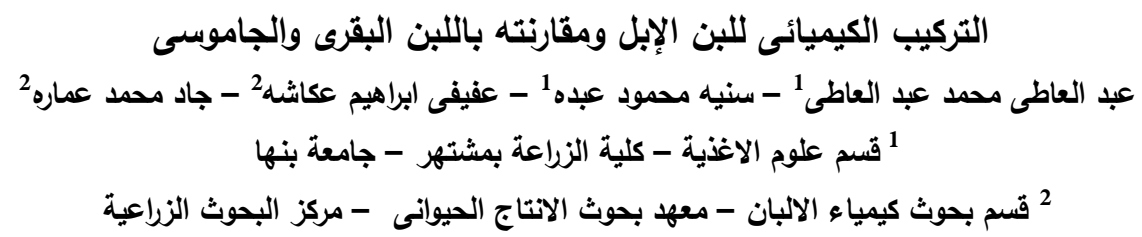

جمعت عينات لبن الإبل من محطة تربية الحيوان التابعة لمعهد بحوث الإنتاج الحيوانى بمرسى مطروح، تم التحليل الكيميائى للعينات وتم

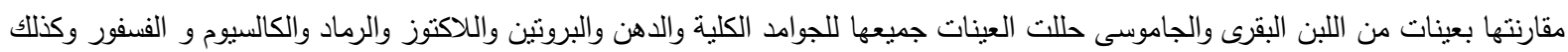

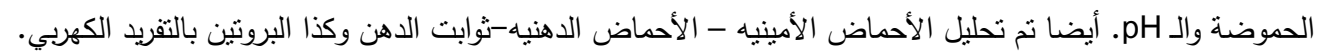
أوضحت النتائج أن لبن الجمال يحتوى على نسبة أقل من اللبن البقرى والجاموسى فى محتواه في كل من الجوامد الكلية والبروتين واللاكتوز والكالسيوم والفسفوروكذلك الحموضة. بينما احتوى لبن الجمال على نسبة من CN/TN أقل من نسبة NPN/TN, WP/TN كانت أعلى منها فى اللبن البقرى والجاموسى وبتقدير الأحماض الأمينية فى اللبن وجدت اختلافات بين لبن الجمال والبقرى والجاموسى فى نسب الأحماض الأمينية وأيضا عند تحليل الأحماض الدهنية وجدت اختلافات كبيرة بين لبن الجمال والبقرى والجاموسى مما أدى إلى إختلافات كذللك فى ثثابت الدهن لهذه الألبان. أدى تحليل البروتين بالتفريد الكهربى إلى إيجاد فروق كثيرة بين لبن الجمال والبقرى والجاموسى وأهمها هو نسبة البيتاكازين فى لبن الجمال فهى أعلى منها في البقى لونى

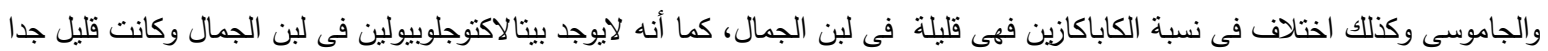
فهو فى ذلك يشابه لبن الأم. 